International Research Journal of Engineering, IT \& Scientific Research
Available online at https://sloap.org/journals/index.php/irjeis/
Vol. 7 No. 2, March 2021, pages: 71-75
ISSN: 2454-2261
https://doi.org/10.21744/irjeis.v7n2.1357

\title{
Gymnastics Reduces the Risk of Falling in the Elderly at Social Centers Elderly Meci Angi Bima
}

Dahlan D. Ahmad ${ }^{a}$ Rostinah $^{b}$

Rini Hendari ${ }^{\mathrm{c}}$

Nurbaety $^{d}$

Article history:

Submitted: 09 December 2020

Revised: 27 January 2021

Accepted: 24 February 2021

\section{Keywords: \\ elderly meci angi; \\ elderly; \\ falling risk; \\ gymnastics; \\ social center;}

\section{Corresponding author:}

Rostinah,

Department of Midwifery

Midwifery Academy Harapan Bunda Bima, Indonesia.

Email address: rostinahsuherman@gmail.com

\begin{abstract}
The Elderly has the risk of falling due to physical weakness resulting in disruption of body balance which can be improved through regular balance exercises to increase the strength of the lower limb muscles. This research aimed at analyzing the effect of before and after gymnastic balance against the risk of falling the elderly at Social Center Meci Angi Bima. The research design that was utilized was a quasi-experimental research design by one group pretest-posttest design. Based on the Paired t-test with a probability value of $95 \%, \alpha=0.05$ showed that $p=0.000(p \leq 0.05)$. The result showed that in this study there is a significant effect between balance gymnastics and the risk of falling in the elderly.
\end{abstract}

International research journal of engineering, IT \& scientific research (C) 2021. This is an open access article under the CC BY-NC-ND license (https://creativecommons.org/licenses/by-nc-nd/4.0/).

${ }^{a}$ Master of Science Nursing, Nursing Department of Mataram Health Polytechnic (Poltekkes Mataram) Bima West Nusa

Tenggara, Indonesia

${ }^{\mathrm{b}}$ Master of Science Midwifery, Midwifery Department of Academy Harapan Bunda, Bima West Nusa Tenggara, Indonesia

${ }^{\mathrm{c}}$ Master of Science Nursing, Nursing Department of Mataram Health Polytechnic (Poltekkes Mataram) Bima West Nusa

Tenggara, Indonesia

${ }^{\mathrm{d}}$ Master of Science Midwifery, Midwifery Department of Academy Harapan Bunda, Bima West Nusa Tenggara, Indonesia 


\section{Introduction}

The number of elderly in Indonesia tends to increase from year to year. Infodatin Health Ministry of Indonesia (2017), increased life expectancy in Indonesia from 68.6 to 70.8 years, and projections in 2030-2035 reach 72.2 years. The logical consequence is the emergence of various health problems that the elderly could potentially face with aging. Aging is a natural process that faces humans, a dynamic and complex process that results from changes in cellular, physiological, and psychological changes. One of the most basic changes in the elderly is a physical change. One of the most frequent physical setbacks or changes is on system musculoskeletal, namely reduced muscle mass, connective tissue stiffness, and osteoporosis. This can cause a decrease in muscle strength, especially the muscles of the extremities under, endurance, and coordination, and limitations range of motion (Miller, 2004).

One of the effects of decreased muscle strength is the occurrence of balance disorders. Balance disorders are a health problem that is often encountered in elderly people. Balance is the basis of human functional movement both in children, adults, and the elderly. Balance is a complex interaction of integration system sensory (vestibular, visual, and somatosensory including proprioceptor) and musculoskeletal (muscles, joints, and other soft tissues) that are modified/regulated in the brain (motor control, sensory, basal ganglia, cerebellum, association areas) as a response to change condition internal and external (Batson, G, 2009). Lower limb muscle weakness can cause balance disorders body, resulting in sluggish movements, short strides, legs unable to tread firmly, and late anticipating when slipped or tripped or fell (Darmojo \& Martono, 2004).

Balance disorders arise with several implications one of which is falling. Every year there are one in three elderly people in the world who are over 65 years old experience a fall. This figure tends to increase with increase. The balance experienced by the elderly is partly due to weakness of the muscles of the body enforcers. The weakness of the upright muscles body this appears because drop degenerative on elderly, this decline is seen in the musculoskeletal field of study where decreased muscle mass massive happen and followed with drop activity functional. Decreased balance in the elderly must be treated to reduce the diagnosis that can increase life expectancy. To overcome balance disorders that result in falls, the elderly need to maintain and improve their balance with to do training (Vuillerme et al., 2001; Pop \& Ciomag, 2014; Vuillerme et al., 2001; Nugraha, 2016).

On this research movement practice use Balance Exercise according to Fabio Comana (2006) Based on observations at the Social Center Elderly Meci Angi Bima, in 2017, it was found that almost every day the elderly experienced trauma due to falls, nearly $20 \%$ of the elderly who fell were injured and even fractured. There were 5 out of 50 elderly who suffered serious injuries due to falls (January-December), the rest had moderate and minor injuries. The data too strengthened from the result interviews conducted with foster care fathers and mothers, as well as the nurses who accompany, say that Most of the elderly have injuries to the legs and arms until they experience fractures so that elderly people experience limitations in their activities. According to some experts, physiological gymnastic movements in the elderly can move the limbs, arms, and torso that will impact on enhancement muscle strength as an effector helps in maintaining a balanced body so that this physical exercise can be used as an alternative to prevent morbidity distraction balance and falls in the elderly. The purpose of this research is to find out the influence of gymnastics elderly people against the risk of falling in the elderly.

\section{Materials and Methods}

Design using quasi-experimental measurement risk fall before and after exercise elderly people trial research use pretest and post-test control design research design. This experimental design allows it to do a pre-test and post-test control design in two groups of respondents, namely the group that gave balance exercise intervention and the group that did not do balance exercise (Purnomo et al., 2015). This research was conducted from June to November 2018 at the Social Center for the Elderly of Meci Angi Bima. The sample in the study amounted to 50 respondents. The data analysis used in this research is descriptive analysis and inferential analysis Descriptive analysis was carried out with present's data through frequency distribution while inferential analysis is used to test the effect of balance exercise on the risk of falling for the elderly at Meci Angi Bima use test Wilcoxon test. 
Table 1

A Simple Example of a Table

\begin{tabular}{|c|c|c|c|c|c|c|c|c|c|}
\hline \multirow{2}{*}{ Risk } & \multicolumn{4}{|c|}{ Without Balance Gymnastics } & \multicolumn{4}{|c|}{ Balance Gymnastics } & \multirow{2}{*}{$P$-Value } \\
\hline & Pre & $\%$ & Post & $\%$ & Pre & $\%$ & Post & $\%$ & \\
\hline Low & 10 & 50 & 12 & 60 & 10 & 33,3 & 14 & 46,7 & \\
\hline Moderate & 8 & 40 & 6 & 30 & 12 & 40 & 11 & 36,7 & Willcoxon \\
\hline High & 2 & 10 & 2 & 10 & 8 & 26,7 & 5 & 16,6 & 001 \\
\hline Total & 20 & 100 & 20 & 100 & 30 & 100 & 30 & 100 & \\
\hline
\end{tabular}

\section{Results and Discussions}

Based on the results of different tests Willcoxon test between the treatment and control groups, indicating that $\mathrm{p}=$ $0.01(\alpha<0.05)$ which means that there is an effect of balance exercise on the risk of falling for the elderly. In Table 1 it can also be seen that most of the risk levels for fall in the elderly, before and after it is given intervention on group Most of the treatments experienced changes in both the risk of falling moderate and high, while in the control group that was not doing balance exercises, only the moderate risk experienced changes. In the elderly there are physical changes, one of which is the musculoskeletal system where the bones become more fragile, the strength and stability of the bones decreased, happen kyphosis, changes in gait, muscle fiber atrophy so that movement becomes slow. These changes can result in slow motion, short strides, power muscle decreased, tend easy wobbly so that have a balance disorder and end up at risk of falling (Crisp et al., 2020).

Balance is the ability to maintain body balance when changing positions. If body balance is not trained on elderly people then will pose major problems to the quality of life of elderly people as fall down and resulting in injury (Setiawan, 2007). There are several therapies used to improve balance wrong one of them is balance exercise (Suhartono, 2005). This is according to research Paramita et al. (2018); Mustika \& Harini (2017) that explained that the combination of elderly exercise and Street tandem could improve the body balance of the elderly as measured using the Berg Balance Scale. In this research, The balance practice performed on 30 respondents in the treatment group was balance exercise for 30 minutes, 15 times a week, 3 times a week. The results of this study are supported by research by Setyoadi et al. (2013), on 40 Elderly at the Gerontology Foundation sub-district Wajak, Malang Regency shows that there is a significant difference in the level of body balance between parents who do body balance exercises and person old that not do the exercises, the elderly who participate in gymnastics have a good balance so that they have a lower risk of falling than the elderly who do not participate in the exercise. The elderly who actively participate in balance exercises will increase muscle strength while maintaining stamina. This is following the theory according to Vuillerme \& Nougier (2004); Asseman et al. (2008).

Basically to achieve balance requires constant training, so that the muscle fibers become stable to accept the movements faced at any time. The Elderly experienced decreased balance due to loss of bone density decreased muscle strength and decreased stamina so that failure to maintain a postural position, so exercise is needed balance To use train balance of the elderly so could prevent the risk of falling. Falling is a direct impact of balance disorders, this can be minimized by risk factors, namely age, physical activity, psychological disorders, use of drugs, certain and disease cardiovascular diseases such as heart disease and hypotension orthostatic. Decline balance can be improved by doing physical exercise because it can keep muscle function and posture stable. One of the physical exercises you can do to upgrade balance that is practice balance exercise. Balance exercise can strengthen weak muscles, improve stiff joints, and train muscle coordination so that the elderly can control the risk of falling (Depkes RI, 2002). This is in line with Suparwati (2017) research which explains that fitness exercise in the elderly is effective in increasing flexibility and balance in the elderly so that it can reduce the risk of falling. Research conducted by Alvita \& Huda (2018) on 58 Elderly in Urhesos Margomukti Rembang, shows there is an influence significant among gymnastics balance against the risk of falling in the elderly, decreased balance can be improved by doing physical exercise because it can keep muscle function and posture stable. One of the physical exercises that can be done to improve balance is exercise. Practice flexibility could upgrade power tendon and ligaments, maintains muscle strength across joints, and reduces pain in osteoarthritis cases so that range of motion can be maintained. Physical activity is every movement body that needs the energy to do it, such as walking, dancing, raising grandchildren, and so on. Planned physical activity and structure, that involves repetitive body movements and aimed at to upgrade fitness physical is called Sports (Pribadi, 2015 \& Farizati, 2002). Among the benefits of exercise

Ahmad, D. D., Rostinah, R., Hendari, R., \& Nurbaety, N. (2021). Gymnastics reduces the risk of falling in the elderly at social centers elderly meci angi bima. International Research Journal of Engineering, IT \& Scientific Research, 
for the elderly extend age, healthy heart, muscles, and bones, make Elderly more independent, prevent obesity, reduce worry and depression, and gain higher self-confidence. Posyandu cadre training is needed in the implementation of balance exercises so that the risk of falling for the elderly can be reduced (Rostinah et al., 2015).

\section{Conclusion}

There is a significant effect of exercise in the elderly on the body balance of the elderly, it is recommended to the Puskesmas officers to To do coaching and supervision of elderly health programs, one of which is by implementing elderly exercise in a manner regular.

Conflict of interest statement

The authors declared that they have no competing interests.

Statement of authorship

The authors have a responsibility for the conception and design of the study. The authors have approved the final article.

Acknowledgments

Health Polytechnic of Ministry of Health at Mataram No: 116/UN18.8/ETIK/2018. 


\section{References}

Alvita, G. W., \& Huda, S. (2018). Pengaruh Senam Keseimbangan Dengan Resiko Jatuh Pada Lansia Di Unit Rehabilitasi Sosial Margomukti Rembang. Prosiding HEFA (Health Events for All).

Asseman, F. B., Caron, O., \& Crémieux, J. (2008). Are there specific conditions for which expertise in gymnastics could have an effect on postural control and performance?. Gait \& posture, 27(1), 76-81. https://doi.org/10.1016/j.gaitpost.2007.01.004

Batson, G. (2009). Update on proprioception: considerations for dance education. Journal of Dance Medicine \& Science, 13(2), 35-41.

Crisp, J., Douglas, C., Rebeiro, G., \& Waters, D. (2020). Potter \& Perry's Fundamentals of Nursing ANZ editioneBook. Elsevier Health Sciences.

Darmojo, R. B., \& Martono, H. H. (2004). Geriatri (ilmu kesehatan usia lanjut). Edisi ke-3. Jakarta: Balai Penerbit FKUI, 3-4.

Depkes RI, (2002). Pedoman Perawatan Kesehatan di Rumah. Derektorat Keperawatan Kesehatan di Rumah. Direktorat Keperawatan, Ditjend. Yanmed: Jakarta.

Fabio, C. (2006). American council on exercise (ACE).

Farizati. (2002). Panduan kesehatan olahraga bagi petugas kesehatan. Jakarta : Depkes RI.

Infodatin. (2017). Pusat Data Dan Informasi Kementerian Kesehatan RI, Tentang Situasi Lanjut Usia (Lansia) Di Indonesia, [Online] available at: [cited 29 Januari 2017.

Miller, C. A. (2018). Nursing for wellness in older adults. Lippincott Williams \& Wilkins.

Mustika, I. W., \& Harini, G. A. (2017). Increasing education of family support for decreasing depression level towards elderly. International Journal of Health Sciences, 1(3), 10-16.

Nugraha, M. H. S., Wahyuni, N., \& Muliarta, I. M. (2016). The pelatihan 12 balance exercise lebih meningkatkan keseimbangan dinamis daripada balance strategy exercise pada lansia di banjar bumi shanti, desa dauh puri kelod, kecamatan denpasar barat. Majalah Ilmiah Fisioterapi Indonesia, 4(1).

Paramita, D. P., Adiatmika, I. G. P., Kuswardhani, T., \& Mustika, I. W. (2018). Physiological and psychosocial change and the need of health intervention model for elderly. International Journal of Health Sciences, 2(2), 6167.

Pop, C., \& Ciomag, V. (2014). The Influence of Aerobic Gymnastics on the Students' Body Image. Procedia-Social and Behavioral Sciences, 117, 129-135. https://doi.org/10.1016/j.sbspro.2014.02.190

Pribadi, A. (2015). Pelatihan Aerobik untuk kebugaran paru jantung bagi lansia. Jorpres (Jurnal Olahraga Prestasi), 11(2).

Purnomo, P., Wijono, W., \& Setijono, H. (2015). Pengaruh Pelatihan Plyometric Knee Tuck Jump dan Step Up Jump terhadap Peningkatan Daya Ledak Otot Tungkai dan Kelincahan. BRAVO'S (Jurnal Prodi Pendidikan Jasmani \& Kesehatan), 3(1), 7-17.

Rostinah, R., Widajanti, L., \& Wulan, L. R. K. Evaluation on Integrated Health Post Cadres Training Management in Paruga Primary Healthcare Centers at Bima City Nusa Tenggara Barat Province. Jurnal Manajemen Kesehatan Indonesia, 3(3), 212-221.

Setiawan, E. (2007). Fleksibilitas dan Senam Sehat Indonesia pada Wanita Usia Lanjut (Doctoral dissertation, Faculty of Medicine).

Setyoadi, S., \& Utami, Y. W. (2013). Senam dapat meningkatkan keseimbangan tubuh lansia di yayasan gerontologi kecamatan wajak kabupaten malang. Jurnal Ilmu Keperawatan: Journal of Nursing Science, 1(1), 35-40.

Suhartono, S. (2005). A comparative study of forecasting models for trend and seasonal time series does complex model always yield better forecast than simple models. Jurnal Teknik Industri, 7(1), 22-30.

Suparwati, K. T. A., Muliarta, I. M., \& Irfan, M. (2017). Senam Tai Chi Lebih Efektif Meningkatkan Fleksibilitas Dan Keseimbangan Daripada Senam Bugar Lansia Pada Lansia Di Kota Denpasar. Sport and Fitness Journal.

Vuillerme, N., \& Nougier, V. (2004). Attentional demand for regulating postural sway: the effect of expertise in gymnastics. Brain Research Bulletin, 63(2), 161-165. https://doi.org/10.1016/j.brainresbull.2004.02.006

Vuillerme, N., Danion, F., Marin, L., Boyadjian, A., Prieur, J. M., Weise, I., \& Nougier, V. (2001). The effect of expertise in gymnastics on postural control. Neuroscience letters, 303(2), 83-86. https://doi.org/10.1016/S03043940(01)01722-0

Vuillerme, N., Teasdale, N., \& Nougier, V. (2001). The effect of expertise in gymnastics on proprioceptive sensory integration in human subjects. Neuroscience letters, 311(2), 73-76. https://doi.org/10.1016/S03043940(01)02147-4

Ahmad, D. D., Rostinah, R., Hendari, R., \& Nurbaety, N. (2021). Gymnastics reduces the risk of falling in the elderly at social centers elderly meci angi bima. International Research Journal of Engineering, IT \& Scientific Research, 